\title{
Zmiany nazw miejscowych na Ślq̨sku Opolskim po 1945 r.
}

\section{STANISŁAWA SOCHACKA}

Państwowy Instytut Naukowy - Instytut Śląski w Opolu

\section{ROCZNIK}

\section{ZIEM}

\section{ZACHODNICH}

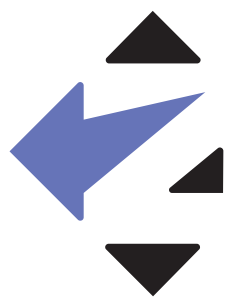




\section{Wstęp}

Przesunięcie na zachód granic państwa polskiego po II wojnie światowej postawiło przed władzami niezwykle istotne zadania polityczne, gospodarcze i kulturalne. Należało jak najszybciej zasiedlić i zagospodarować cały obszar Polski Zachodniej i Północnej, a także przywrócić miastom, wsiom, rzekom i górom ich dawne polskie nazwy lub też zastąpić nazwy niemieckie polskimi „chrztami”, gdyż dotąd dane obiekty ich nie miały. Państwo nie mogło funkcjonować bez polskich nazw, należało więc jak najszybciej uregulować kwestię nazewnictwa. Powojenna rzeczywistość zaczęła się bowiem rządzić swoimi prawami. Napływająca ludność nadawała polskie nazwy poszczególnym miejscowościom zupełnie dowolnie, według własnego uznania. Nie respektowano względów historycznych, językowych ani naukowych. Żywiołową działalność nazwotwórczą podjęły także lokalne władze państwowe i administracyjne (dyrekcje kolei, poczta, starostwa).

Doszło do ogólnego zamętu i chaosu. Niektóre obiekty miały po trzy, a nawet cztery nazwy. W tej sytuacji po usilnych staraniach grupy uczonych krakowskich, skupionych wokół Polskiej Akademii Umiejętności (PAU), została utworzona (wskrzeszona) Komisja Ustalania Nazw Miejscowości przy Ministerstwie Administracji Publicznej, organ opiniodawczo-doradczy w sprawach ustalania, dokonywania zmian i znoszenia urzędowych nazw geograficznych ${ }^{1}$.

Komisja postawiła sobie dwa zasadnicze cele: ogólnopaństwowy i ogólnospołeczny. Pierwszy wynikał z potrzeby zamanifestowania polskości tych ziem, stąd dążenie do przebadania wielkiej liczby źródeł historycznych i wydobycia nazw polskich z ich poświadczeniami historycznymi. Racje ogólnospołeczne polegały na szybkim włączeniu nowych nazw w sprawny obieg komunikacji językowej, tak aby mogły one służyć administracji, kulturze, turystyce i innym dziedzinom życia.

Celem artykułu jest przedstawienie i ocena procesu ustalania nazw miejscowych na Śląsku Opolskim po 1945 r. Autorka czyni to z pozycji językoznawcy-onomasty,

1 Przypomnijmy, że pierwsza Komisja Ustalania Nazw Miejscowości utworzona została w 1934 r. przy Ministrze Spraw Wewnętrznych na podstawie Rozporządzenia Prezydenta Rzeczypospolitej z 24 X 1934 r. W styczniu 1946 r. reaktywowano ją z inicjatywy Ministra Administracji i Ministra Ziem Odzyskanych przy Ministerstwie Administracji Publicznej. W roku 1948 nastąpiła zmiana nazwy na Komisję Ustalania Nazw Miejscowości i Obiektów Fizjograficznych (dekret z 28 I 1948 r., opublikowany w „Dzienniku Ustaw” nr 36, poz. 251). W roku 1950 Komisje przeniesiono do Urzędu Rady Ministrów i podporządkowano Prezesowi Rady Ministrów. Na mocy ustawy z 29 VIII 2003 r. o urzędowych nazwach miejscowości i obiektów fizjograficznych zmieniono jej nazwę na Komisja Nazw Miejscowości i Obiektów Fizjograficznych (Dz.U. 2003, Nr 166, art. 4). Zanim doszło do reaktywacji Komisji Ustalania Nazw Miejscowości z inicjatywy Dyrekcji Okręgowej Kolei Państwowej w Poznaniu zorganizowano w Szczecinie zjazd onomastyczny poświęcony nazewnictwu Ziemi Lubuskiej i Pomorza Zachodniego. Nie zostali zaproszeni na ten zjazd uczeni krakowscy i Instytutu Śląskiego w Katowicach, zob. T. Białecki, Pierwszy Zjazd Onomastyczny w Szczecinie (11-13 IX 1945), „Przegląd Zachodniopomorski”, t. XXV (1981), z. 3-4, s. 105-115. 
opierając się na najnowszym stanie badań i śląskiej syntezie nazewniczej², które zawierają pełną dokumentację historyczną nazw geograficznych od X do XX w., w tym także nazwy przejściowe, używane samorzutnie przez ludność i urzędy w latach 1945-1948³. Nader pomocna była monografia Henryka Borka4, przedstawiająca obraz stosunków etnicznych niemiecko-polskich na podstawie osadnictwa. Komponując niniejszy tekst, świadomie zrezygnowano z przedstawienia wpływu czynników politycznych, pozajęzykowych na rugowanie języka polskiego na Śląsku począwszy od czasów średniowiecza, poprzez kolonizację fryderycjańską aż po czasy nazistowskie. Problem ten został ukazany w odrębnej publikacji ${ }^{5}$.

W dotychczasowych badaniach przemian nazewniczych w okresie powojennym zarysowały się dwa kierunki badawcze: instytucjonalny, skupiający się na działalności Komisji Ustalania Nazw Miejscowości ${ }^{6}$, i terytorialny ${ }^{7}$, przedstawiający ustalanie nazw miejscowości w poszczególnych polskich regionach.

2 S. Rospond, Słownik etymologiczny nazw geograficznych Ślqsska, t. 1: A-B, Warszawa-Wrocław 1970; Słownik etymologiczny nazw geograficznych Śląska, t. 2: C-E, red. S. Rospond, H. Borek, Warszawa-Wrocław 1985; Słownik etymologiczny nazw geograficznych Ślqska, t. 3: F-G, red. S. Rospond, H. Borek, Warszawa-Wrocław 1986; Słownik etymologiczny nazw geograficznych Ślqskka, t. 4: H-Ki, red. H. Borek, Warszawa-Wrocław 1988; Słownik etymologiczny nazw geograficznych Ślaska, t. 5: Kl-Kos, red. S. Sochacka, Opole 1991; Słownik etymologiczny nazw geograficznych Ślqska, t. 6: Kos-Lig, red. S. Sochacka, Opole 1992; Słownik etymologiczny nazw geograficznych Śląska, t. 7: Lig-Miez, red. S. Sochacka, Opole 1994; Słownik etymologiczny nazw geograficznych Ślaska, t. 8: Mie-Niż, red. S. Sochacka, Opole 1997; Słownik etymologiczny nazw geograficznych Ślqska, t. 9: Noc-Path, red. S. Sochacka, Opole 1999; Słownik etymologiczny nazw geograficznych Ślqska, t. 10: Pato-Poz, red. S. Sochacka, Opole 2002; Słownik etymologiczny nazw geograficznych Ślq̨ska, t. 11: Poż-Roz, red. S. Sochacka, Opole 2004; Słownik etymologiczny nazw geograficznych Ślqska, t. 12: Roż-Sów, red. S. Sochacka, Opole 2005; Słownik etymologiczny nazw geograficznych Ślaska, t. 13: Spad-Szyw, red. S. Sochacka, Opole 2007; Słownik etymologiczny nazw geograficznych Ślaska, t. 14: Ściana-Weł, red. S. Sochacka, Opole 2009; Słownik etymologiczny nazw geograficznych Ślaska t. 15: Wem-Wrzes, red. S. Sochacka, Opole 2011; Słownik etymologiczny nazw geograficznych Ślqska, t. 16: Wrzesień-Żyznów, red. S. Sochacka, Opole 2014; Słownik etymologiczny nazw geograficznych Slasska, t. 17: Suplement A-Ż, red. S. Sochacka, Opole 2016; M. Choroś, Ł. Jarczak, S. Sochacka, Słownik nazw miejscowych Ślaska polsko-niemiecki i niemiecko-polski, Opole 2015.

3 M. Choroś, Ł. Jarczak, Wykaz przejściowych nazw miejscowych na Opolszczyźnie w latach 1945-1948 „Onomastica”, t. XLIII (1998), s. 53-80.

H. Borek, Opolszczyzna w świetle nazw miejscowych, Opole 1972.

5 S. Sochacka, Polsko-niemieckie stosunki nazewnicze na Ślasku w pierwszej połowie XX wieku, „Studia Śląskie", t. LXXVI (2015), s. 79-89.

6 O działalności Komisji napisano wiele prac, np. K. Rymut, Działalność powojennej Komisji Ustalania Nazw Miejscowości z perspektywy kilkudziesiecciu lat, "Zeszyty Naukowe Wydziału Humanistycznego Uniwersytet Gdański. Filologia Polska. Prace Językoznawcze”, nr 10 (1984), s. 87-91; idem, Działalność Komisji Ustalania Nazw Miejscowości i Obiektów Fizjograficznych w latach 1978-2003, "Onomastica”, t. XLVIII (2003), s. 315-328; M. Wagińska-Marzec, Ustalanie nazw miejscowości na Ziemiach Zachodnich i Północnych, [w:] Wokół niemieckiego dziedzictwa kulturowego na Ziemiach Zachodnich i Północnych, red. Z. Mazur, Poznań 1997, s. 369-416.

7 W. Iwicki, Ocena reslawizacji nazw miejscowych w byłym powiecie słupskim przez KUNM, „Zeszyty Naukowe Wydziału Humanistycznego - Uniwersytet Gdański. Filologia Polska. Prace Jezykoznawcze", nr 11 (1985), s. 37-41; B. Linek, Zmiany nazw na Górnym Ślqsku w XIX i XX w., [w:] Nazwa dokumentem przeszłości regionu, red. J. Nowosielska-Sobel, G. Strauchold, W. Kucharski, Wrocław 2010, s. 123-134 J. Nowosielska-Sobel, „Matecznik sprzeczności?”. Spór o „właściwe nazwy” na Dolnym Ślqsku po II wojnie światowej $w$ świetle prasy regionalnej, [w:] Nazwa dokumentem przeszłości..., s. 221-237; E. Rzetelska-Feleszko, Zagadnienia poprawności dzisiejszych nazw geograficznych na Pomorzu Zachodnim, [w:] Język i jego odmiany $w$ aspekcie porównawczym, red. J. Majowa, Wrocław 1986, s. 149-161; E. Rymar, Ocena ustalania nazw miejscowych na obszarze dawnej Nowej Marchii przez Komisję Ustalania Nazw Miejscowych w latach 1946-1949, „Onomastica”, t. XXX (1986), s. 51-68; G. Strauchold, Dyskusja wokół polskiego nazewnictwa tzw. Ziem Odzyskanych w latach 40. XX w., [w:] Nazwa dokumentem przeszłości..., s. 21-34; M. Wagińska-Marzec, Jak zmieniano nazwy miejscowości na Warmii i Mazurach po 1945 r., [w:] Wspólne dziedzictwo? Ze studiów nad stosunkiem do spuścizny kulturowej na Ziemiach Zachodnich i Północnych, red. Z. Mazur, Poznań 2001, s. 59-107; S. Sochacka, Problematyka Ślq̨ska w działalności Komisji Ustalania Nazw Miejscowości i Obiektów Fizjograficznych (ze szczególnym uwzględnieniem lat 1989-2009), „Studia Śląskie", t. LXIX (2010), s. 195-215. 
W świetle współczesnego stanu badań niniejsze opracowanie wpisuje się w nurt analiz uzupełniających jedną z luk dotyczących Śląska Opolskiego. Regionu, który jest częścią wielkiej historycznej dzielnicy, w przeszłości zróżnicowanej plemiennie, jak czytamy w Geografie Bawarskim z IX w. Mieszkało tu plemię słowiańskie Opolini (Opolanie), nazwane tak od grodu Opole. Zajmowali oni teren nad górną Odrą i jej dopływami: Kłodnicą, Osobłogą, Małą Panwią i prawdopodobnie częściowo nad Nysą Kłodzką. Ze względu na dobre nawodnienie i żyzne gleby obszar ten należał do najwcześniej zaludnionych ${ }^{8}$. Dziś są to dawne powiaty: brzeski, głubczycki, grodkowski, kluczborski, kozielski, namysłowski, niemodliński, oleski, opolski, prudnicki, raciborski i strzelecki. Żyła tu ludność etnicznie polska przez wieki trwająca przy polskości, a poświadczają to m.in. słowiańskie, polskie nazwy miejscowości. Nic przeto dziwnego, że odważni, uczciwi Niemcy określali je „sprawiedliwym trybunałem historii". W opinii polskich uczonych takim "sprawiedliwym sędzią" po 1945 r. stała się Komisja Ustalania Nazw Miejscowości ${ }^{10}$.

Niemałą rolę w działaniach Komisji Ustalania Nazw Miejscowości odegrał Instytut Śląski w Katowicach, pod kierownictwem dr. Romana Lutmana, który zaczął funkcjonować w styczniu 1945 r. pod opieką PAU w Krakowie, a wkrótce, w połowie lutego, został przeniesiony do Katowic, gdzie powrócił do swojej przedwojennej siedziby i dawnych form organizacyjnych.

\section{Udział Instytutu Śląskiego w Katowicach w pracach Komisji Ustalania Nazw Miejscowości}

Komisja Ustalania Nazw Miejscowości została powołana z potrzeby społecznej, która wynikała $\mathrm{z}$ chaosu i zamętu w nazewnictwie na tzw. Ziemiach Odzyskanych. Społeczeństwo nie zdawało sobie sprawy z tego, że porządkowanie i zmiany nazw należą do kompetencji specjalnej instytucji, którą przed wojną była Komisja Ustalania Nazw Miejscowości przy Ministerstwie Spraw Wewnętrznych.

Ludność i administracja oznaczały różne miejscowości przypadkowo dobranymi nazwami, np. Omyśl, Domusz, Lipiszk, Budych, Homsica itd. (Kartogram Dyrekcji Okręgowej Kolei Państwowej w Poznaniu, nr 102 z 12 lipca 1945 r.). Były to dowolnie poskładane litery bez jakiegokolwiek sensu. Wszystkie te antyustawowe, samorodne poczynania władz lokalnych (Poznania, Katowic, Wrocławia, Opola, Kłodzka) spotkały się z ostrą krytyką przedstawicieli nauki. W latach 1945-1946 opublikowano w prasie i czołowych czasopismach artykuły znanych uczonych polskich, które 
wskazywały na niekompetencję władz lokalnych ${ }^{11}$. Autorzy podkreślali, że sprawy tak ważne dla narodu i państwa powinny rozstrzygać nie instytucje lokalne, lecz władze centralne.

Na postulaty te jako pierwszy zareagował Roman Lutman, dyrektor Instytutu Śląskiego w Katowicach, zwracając się do PAU, aby zajęła się nazwami miejscowymi Śląska ${ }^{12}$. Odpowiedzią na apel Lutmana było powołanie Komitetu Nazw Geograficznych przy PAU, któremu przewodniczyli prof. prof. Władysław Semkowicz i Witold Taszycki, przy współpracy Stanisława Urbańczyka, Franciszka Sławskiego, Zofii Budkowej i Tadeusza Nowaka, o czym czytamy:

Zdając sobie dokładnie z tego sprawę, iż z usiłowań dyrekcji Okręgowej Kolei Państwowych w Poznaniu nic dobrego w tym względzie nie wyjdzie, postanowił Instytut Śląski w Katowicach w porozumieniu z Polską Akademią Umiejętności powierzyć opracowanie śląskich nazw miejscowych utworzonej w lipcu 1945 r. przez obie te instytucje sześcioosobowej Komisji. Na jej czele stanęli historyk Władysław Semkowicz i językoznawca, autor niniejszego artykułu $[\ldots]^{13}$.

W pracach wielu autorów podkreśla się wkład Instytutu Śląskiego w Katowicach w utworzenie Komitetu Nazw Geograficznych, w ramach którego działała Komisja Śląska. Do niej należała koordynacja prac, gromadzenie materiału historycznego i rozstrzyganie wszelkich kwestii spornych. Komisja ta przekształciła się w Komisję Regionalną I opracowującą nazwy Śląska ${ }^{14} \mathrm{w}$ ramach nowo utworzonej Komisji Ustalania Nazw Miejscowości.

Dzięki aktywnej pracy Komitetu Nazw Geograficznych mogła PAU wystąpić z wnioskiem do ministra administracji i ministra Ziem Odzyskanych o powołanie urzędowego organu ustalania nazw miejscowości ${ }^{15}$. Inicjatorem i autorem pisma był prof. Kazimierz Nitsch, wybitny dialektolog, obrońca polskości Śląska i przedwojenny współpracownik Instytutu Śląskiego.

11 K. Nitsch, Nazwy miejscowe w odzyskanej Polsce Zachodniej, „Jezyk Polski”, R. XXV (1945), nr 2, s. 33-41; W. Taszycki, W obronie ślquskich nazw miejscowych, „Zaranie Śląskie”, R. XVII (1946), s. 52-55; M. Rudnicki, Pierwszy zjazd językoznawców polskich w Szczecinie, „Polska Zachodnia”, nr 8 (1945), s. 11; S. Urbańczyk, Porzqdkowanie nazw miejscowych, „Przegląd Zachodni”, nr 2 (1947), s. 836-841.

12 T. Stojanowska, Kazimierz Nitsch a Ślqqsk. Zwiqzzki naukowe i kontakty osobiste, Opole 1970, s. 50.

13 W. Taszycki, $W$ obronie ślqskich nazw..., s. 54.

14 Zob. B. Olszewicz, O naprawe nazewnictwa geograficznego Ziem Odzyskanych, Gdańsk 1946, s. 10 12; S. Urbańczyk, Poczq̨tki działalności Głównej Komisji Ustalania Nazw Miejscowości na Ślqsku i Ziemi Lubuskiej (wspomnienia), [w:] Gwary i nazewnictwo na Ziemiach Zachodnich i Północnych, red. E. Homa, Zielona Góra 1998, s. 24

15 Archiwum Polskiej Akademii Nauk (dalej: APAN), Oddział w Krakowie, sygn. K III-51, J. 154; Pismo sekretarza generalnego PAU prof. Tadeusza Kowalskiego, s. 1-2; Archiwum Akt Nowych (dalej: AAN), zespół: Ministerstwo Ziem Odzyskanych, sygn. 79; K. Nitsch, List do ministra Ziem Odzyskanych. Departament Ogólny - Gabinet Ministra (Kultura, sztuka, oświata na Ziemiach Zachodnich, Korespondencja 1945-1948). Tu też obszerny cytat z pisma PAU z 18 VIII 1945 r. 
Nitsch zabrał jednocześnie publicznie głos na łamach „Języka Polskiego”, tak pisząc:

Bo oto z inicjatywy Polskiej Akademii Umiejętności i przy współdziałaniu z Instytutem Śląskim powstała w Krakowie Komisja ustalająca śląskie nazwy miejscowości, kierują nią prof. W. Semkowicz i lingwiści prof. W. Taszycki, z którym współpracują docent St. Urbańczyk i dr F. Sławski. Dopiero taki według metod naukowych pracujący zespół daje rękojmię dobrych rezultatów ${ }^{16}$.

Postulaty Nitscha zainteresowały ministra administracji publicznej, który zwrócił się do krakowskiego uczonego z prośbą o przedłożenie projektu w tej sprawie. Ten zaś odpowiedział obszernym listem, przedstawił stan panujący w nazewnictwie Ziem Zachodnich i Północnych i wskazał na konieczność powołania Komisji Centralnej, proponując jej skład i formy organizacyjne ${ }^{17}$.

W styczniu 1946 r. została powołana Komisja Ustalania Nazw Miejscowości. W jej skład weszli prof. Stanisław Srokowski jako przewodniczący, wybitny geograf, dyrektor Instytutu Bałtyckiego w Toruniu, trzej językoznawcy: prof. prof. Kazimierz Nitsch, Mikołaj Rudnicki (Poznań) i Witold Taszycki oraz przedstawiciele czterech ministerstw: Administracji, Komunikacji, Obrony Narodowej oraz Poczt i Telegrafów. Powołano też zastępców członków: prof. prof. Stanisława Rosponda (Wrocław), Ludwika Zabrockiego (Poznań) i Stanisława Urbańczyka (Kraków). Instytut Śląski w Katowicach reprezentował doc. Antoni Wrzosek, geograf - zastępca dyrektora Romana Lutmana. Pierwsze posiedzenie organizacyjne Komisji odbyło się 3-4 marca 1946 r. Na zebraniu tym powołano trzy podkomisje: Komisję Regionalną I pod przewodnictwem Witolda Taszyckiego, Komisję Regionalną II (przewodniczący Witold Taszycki) i Komisję Poznańską pod przewodnictwem Mikołaja Rudnickiego.

Prace nad nazewnictwem śląskim rozpoczęto już w lipcu 1945 r. w ramach Komitetu Nazw Geograficznych, przy którym powstała Komisja Śląska, przekształcona w Komisję Regionalną I. Po półrocznych wysiłkach, a zatem tuż przed powołaniem Głównej Komisji Ustalania Nazw Miejscowości ${ }^{18}$, jej prace zostały zakończone. Podstawowym zadaniem Komisji Śląskiej było wyekscerpowanie ostatniego oficjalnego niemieckiego spisu śląskich miejscowości ${ }^{19} \mathrm{i}$ porównanie go ze szczególnie cennym, sprzed stu laty, spisem nazw miejscowości opracowanym przez Johanna Georga Kniego ${ }^{20}$. W ten sposób ustalono, którym nazwom należy przywrócić dawną formę polską, a którym nową nazwę polską nadać. Historycy przystąpili jednocześnie 
do wydobywania ze źródeł historycznych, z dawnych dokumentów i kronik, utrwalonych w nich śląskich nazw miejscowych. Powstała w ten sposób wielotysięczna kartoteka nazw ciągle uzupełniana. Dopiero na jej podstawie językoznawcy mogli przystąpić do zasadniczej części pracy, tj. prawidłowego odczytania zniekształconych nazw miejscowości.

Cały ten wielki zbiór (sporządzony z wydatną pomocą Instytutu Śląskiego) ${ }^{21}$ przejęła Komisja Regionalna I, przygotowująca na jej podstawie projekty nazw dla Komisji Głównej22. Językoznawcy stali na straży języka, ustalali brzmienia i pisownię współczesną nazw, wytyczali właściwe granice w zastosowaniu cech regionalnych i form literackich. Uchwały Komisji Głównej zatwierdzał Minister Administracji Publicznej i Ziem Odzyskanych i ogłaszał je w „Monitorze Polskim”.

W pracach Komisji Ustalania Nazw Miejscowości Śląsk zdecydowanie się wyróżniał. Pisze o tym jeden z jej członków: „Śląsk jednak będzie górował, bo zapisy będą w większym komplecie, a rekonstrukcja językowa bardziej fachowa. [...] Niewątpliwie analogiczne dzieło da nam Poznań dla Ziemi Lubuskiej, ale niestety nie rozporządza ten teren takim zasobem dokumentów od czasów najdawniejszych jak Śląsk"23.

Ta olbrzymia masa śląskich nazw historycznych dotrwała do naszych czasów, bo wzorowa niemiecka administracja broniła się zawsze przed zmianami nazw, żeby nie spowodować zamieszania w praktyce. Przeciętni Niemcy byli przekonani, że wszystkie nazwy na niemieckich terenach wschodnich są staroniemieckie (urdeutsch).Zasadniczo Komisji Ustalania Nazw Miejscowości chodziło o to, aby nowe nazwy śląskie miały prawdziwie polskie oblicze, by piastowski Śląsk nadal łączyły z Polską, a wszystko było dowodem porządku i świadectwem solidnej pracy naukowej.

Niemal wszystkie nazwy (95\%) były zatwierdzane w brzmieniu ustalonym przez Komisje Regionalne, jedynie co do nielicznych toczyły się ożywione dyskusje. W ciągu pięciu lat Komisja Główna odbyła czternaście posiedzeń, przeciętnie trzy w roku. W całości ustalono na Ziemiach Odzyskanych 32138 nazw miejscowości. Komisja zakończyła swe prace w 1950 r. Ustalone przez nią wszystkie nazwy zostały opublikowane przez Stanisława Rosponda ${ }^{24}$.

\section{Repolonizacja nazw miejscowych Śląska Opolskiego}

Używane obecnie (2016) na Śląsku Opolskim nazwy - podobnie jak na całych Ziemiach Zachodnich i Północnych - zostały ustalone i wprowadzone w życie w latach 1946-1947. Za przygotowanie projektów dla Komisji Głównej osobiście odpowiadali Witold Taszycki i Stanisław Urbańczyk. Ustalanie nazw przebiegało z wielorakimi trudnościami.

\footnotetext{
21 Kartoteka ta znajduje się w Instytucie Języka Polskiego PAN w Krakowie, jest to obraz wytężonej pracy tej podkomisji.

22 S. Urbańczyk, Porzq̨dkowanie nazw miejscowych..., s. 841.

23 Ibidem

24 S. Rospond, Słownik nazw geograficznych Polski Zachodniej i Północnej według uchwał Komisji Ustalania Nazw Miejscowych pod przewodnictwem S. Srokowskiego, cz. 1: Polsko-niemiecka, cz. 2: Niemiecko-polska, Wrocław 1951
} 
Ścierały się wewnątrz Komisji m.in. różne stanowiska. Wiele kłopotów było z nazwami: Nysa, Prudnik, Głubczyce. Protestowali również mieszkańcy, zwłaszcza tam, gdzie po rocznym pobycie zdążyli się już zadomowić i przyzwyczaić do nazwy, którą zastali lub sami nadali. Komisja, a razem z nią ministerstwo, nie ustępowały, zwłaszcza gdy zwalczana nazwa już była ogłoszona w „Monitorze Polskim”.

Nazwy Śląska Opolskiego nie były zbyt trudne do repolonizacji. Znacznie trudniejsze do przywrócenia były nazwy pomorskie czy byłych Prus Wschodnich, gdzie występowało dużo nazw pochodzenia litewskiego, w dodatku „przekręconych” przez Niemców.

Do nazw wiernie odtworzonych na Śląsku Opolskim należą przede wszystkim nazwy miast: Biała (Zülz), Brzeg (Brieg), Grodków (Grottkau), Kędzierzyn (Kandrzin), Koźle (Cosel), Namysłów (Namyslau), Opole (Oppeln), a także tysiące wsi i przysiółków: Babienica (Babinitz), Bieńkowice (Benkowitz), Dębina (Dambine), Krężel (Krensel).

Oceniając z perspektywy lat pracę Komisji Ustalania Nazw Miejscowości, można zauważyć następujące tendencje:

1) możliwie dokładna językowa rekonstrukcja dawnych nazw oparta na zapisach historycznych;

2) powierzchowna i nieścisła polonizacja nazw polskich przejętych przez język niemiecki i funkcjonujących w nim do 1945 r., odbiegająca od zapisów i etymologii;

3) nadanie nazw zupełnie nowych miejscowościom, które przed $1945 \mathrm{r}$. miały od początku nazwy niemieckie. Są to wyłączne twory Komisji, tzw. chrzty, ustalane według wytycznych regulaminu Komisji, w którym czytamy:

Dla miejscowości, które nie mają poświadczonej historycznie nazwy polskiej ustala się nazwy według następujących zasad:

1) Nazwy nadaje się od najbliższej miejscowości zaginionej, której nazwa rodzima przetrwała, względnie od najbliższej zachowanej nazwy topograficznej (rzeka, góra, jezioro, las, bagno, niwa, łąka, uroczysko);

2) W braku tych przesłanek uwzględnia się nazwy, nadane samorzutnie przez obecnych osadników, względnie przez polskie władze administracji ogólnej, kolejowej, pocztowej lub innej, jeżeli są poprawne z językowego punktu widzenia i nie pozostają w sprzeczności ze względami historycznymi, geograficznymi i administracyjnymi;

3) W ostateczności członkowie Komisji wysuwają własne propozycje, uzasadnione położeniem topograficznym miejscowości, przypuszczalnym rozwojem stosunków osadniczych, harmonizujące z resztą zachowanych w okolicy nazw polskich;

4) Tłumaczenia nazw niemieckich unika się z zasady.

Analogia treści nazwy niemieckiej i polskiej dopuszczalna jest tylko wtedy, jeżeli jest rzeczowo uzasadniona (tzn. nawiązuje do jakiejś rzeczywistej cechy osady, np. Eichwerder Dąbie itp. $)^{25}$. 
Łącznie Komisja przywróciła 1720 nazw na Śląsku Opolskim (wraz z nazwami niemieckimi). Oto charakterystyka najważniejszych grup.

\section{Nazwy zrekonstruowane prawidłowo}

Do tej grupy zaliczono nazwy o starym rodowodzie słowiańskim, których odczytanie z najstarszych dokumentów nie sprawiało żadnych trudności, bo zwykle polegało na zmianie pisowni i sufiksu. Ogólnie do tej grupy można zakwalifikować około 1377 nazw.

Na podstawie najstarszych źródeł z XII-XIII w. - pisanych po łacinie z wielką dokładnością - udało się nadać z powrotem rdzennie polskie nazwy. W bardzo wielu wypadkach Komisja opierała się na opracowaniach śląskich nazw Konstantego Damrota $^{26}$ i Antoniego Wrzoska ${ }^{27}$. Od połowy XIV w. pojawiają się zapisy niemieckie, w których formy słowiańskie mocno się zniekształciły. Spośród różnych zapisów historycznych, odnoszących się do jednej i tej samej nazwy, wybierano tę, która jest zachowana $\mathrm{w}$ żywej mowie. Oto przykłady nazw poprawnie zeslawizowanych: Belka $1556^{28}$ - Bełk, Bronitz 1266 - Broniec, Białulug 1845 - Biały Ług, Glussina 1300 - Głuszyna, Crampna 1300 - Krępna, Istbisco 1318 - Izbicko (od stpol. izdba „dom”), Mockra 1365 - Mokra, Neuniz 1226 - Niwnica, Pleschnicz 1410 - Pleśnica, Pransina 1223 - Prężyna, Rogalici 1300 - Rogalice, Schemischow 1439 - Szymiszów, Tenczinau 1783 - Tęczynów, Wolentzin 1717 - Wolęcin, Zachrov, Zacrov 1312 - Zakrzów, Zalese 1226 - Zalesie, Ziroua 1302 - Żyrowa.

W wielu wypadkach Komisja sięgała do starych nazw wypartych przez nazwy niemieckie: Crziwizna sive Soninwald - Krzywizna (Schönwald 1300), Gat sive Heyda - Gać (Heidau 1300), Jessenicza vulgariter Hermansdorf - Jasienica (Hermsdorf 1282), Radzicowitz sive Steffansdorf - Radzikowice (Stephansdorf 1300).

Ludność tubylcza i napływowa Śląska Opolskiego odrzuciła po 1945 r. nazwy niemieckie. W tej sytuacji nazwy urzędowe zostały społecznie przyjęte. Nie były więc one odczuwane jako sztuczne czy narzucone. Weszły po prostu w system językowy, którym posługiwała się miejscowa ludność, spełniając swoją komunikacyjną formę.

\section{Nazwy nieściśle zrekonstruowane}

Pośpiech, z jakim musiała pracować Komisja Ustalania Nazw Miejscowości, nie mógł nie odbić się niekorzystnie na jakości jej pracy. Popełnione błędy wynikały najczęściej z nieznajomości najstarszych zapisów i form gwarowych używanych w terenie.

\footnotetext{
26 K. Damroth, Die älteren Ortsnamen Schlesiens, ihre Enstehung und Bedeutung, mit einem Anhange über die schlesisch-polnischen Personennamen, Beuthen 1896.

27 Skorowidz gmin Ślqska Dolnego i Opolskiego z niemieckimi i polskimi nazwami miejscowości według
} stanu z dnia 1 stycznia 1941 r., oprac. A. Wrzosek, Katowice 1945.

28 Najpierw podaje się formę źródłową z datą, a potem nazwę ustaloną przez Komisję. 
Wśród nazw „odtwarzanych” przez Komisję znalazły się takie, których zapisy dawały podstawę do innej rekonstrukcji, np.: Braciszów (Bratricowitz 1265) powinien brzmieć Bratrzykowice, Dziekaństwo (Dicanowitz 1563) - Dziekanowice, Grądy (Herzmanowitz 1300) - Hermanowice, Piłka (Pylatowiz 1300) - Piłatowice, Słoków (Slokowicz 1379, Slowkowicz 1416) - Sławkowice, Podłężek (Scorosowins 1263) Skoroszów, Krowiarki (Cravar 1223, Krawarsz 1679) - Krawarze, gw. Krawarz, bo to nazwa $\mathrm{z}$ terenu pogranicza polsko-czeskiego, por. czeską nazwę Kravaře, Biadacz (Uyezdez 1260) - Ujeździec, Przylesie (Pamrbowitz villa vel Cunradswaldt 1300) Pęporowice, niemieckie Konradiswaldau, Skowronów (Czykowitze 1531) - Szychowice, niemieckie Schichowitz.

Przykładem innych deformacji starych nazw śląskich są m.in. następujące nazwy: Ogiernicze (Złogiewniczau XVII w., Logewnice 1679), zapisy historyczne należało odczytać jako Łagiewnicy - Łagiewniki ${ }^{29}$, Szymonia (z Symonowicz 1472) Szymonowice. Nazwę Szymonia Komisja przyjęła według Kniego. To źródło często podawało zniekształcone nazwy polskie.

Są też nazwy o tym samym charakterze odtworzone w sposób bardziej dowolny. Możemy się jednak domyślać, że Komisji chodziło o tzw. poprawność językową, to czy „pasują" do krajobrazu śląskiego, ustalono np. Chwalęcice (Schreiberowe, Schreiberow 1845) - zamiast Szrajberowe, Michowice (Sybracze vel Lewsteyn 1300) - Żebracze, Borownica (Leschnioken) - Leśniaki, Borucice (Borote, Baruthe 1845) - Boruty, Nowaki (Nowak 1291, Nowaków 1309) - Nowaków, Lutoszów (Schroll 1845) - Szrol (od nazwiska niemieckiego Schroll). Tendencja do poprawności literackiej widoczna jest w nazwie Choruła (Chorula 1300), gw. Chorula (od 1996 r. Chorula). Formę Choruła pseudopoprawną wprowadził Knie.

Następną, najmniej liczną grupą są nazwy izolowane, czasem dziwaczne, ponieważ ich podstawy są bez pokrycia, np. Baborów (Baurov 1303, Baworob 1340) - zamiast Baworów od nazwiska czeskiego Bawor „Bawarczyk”, założycielem osady był Bawor ze Strakonic w Czechach; Boboluszki (Bobolusky 1289), gw. Babołuski - zamiast Bobołuski. Jest to nazwa utworzona od przezwiska Bobołuski „łuszczący bób”, por. czeskie Hracholusky „łuszczący groch”.

Na tych i wielu innych przykładach można się przekonać, że Komisja nie zawsze potrafiła należycie wniknąć w strukturę morfologiczną czy fonetyczną badanej nazwy. Ustalano nazwę polską za niemieckimi zapisami, np. Dziekaństwo od urzędowej nazwy niemieckiej Dziekanstwo, Dechansdorf 1936. W sumie nazw wątpliwych na obszarze Opolszczyzny jest łącznie 30. W znakomitej większości w pracach Komisji wyraża się troska o poprawną reslawizację. Nasze aktualnie krytyczne spojrzenie wynika z bogatszego materiału źródłowego i z postępu wiedzy onomastycznej. 


\section{Polonizacja nazw niemieckich}

Nazewnictwo niemieckie na Śląsku Opolskim pochodzi z różnych okresów historycznych. Najmocniej i najwcześniej germanizowaną częścią tego obszaru były powiaty: brzeski, grodkowski, nyski i prudnicki. Początkowo napływający koloniści nie stanowili większości i szybko się asymilowali. Dowodzą tego najstarsze nazwy niemieckie, które się polonizowały, tworząc tzw. nazwy mieszane. Dla całego Śląska można odnotować ich około 100, a dla Śląska Opolskiego tylko 6. Są to następujące nazwy: Dytmarów (villa Ditmari 1284, Ditirsdorf 1484), Kluczbork (Cruceburch 1252), Ferląt (in Hurchlanth 1335, Fredeland 1447) - dziś Korfantów - nazwa pamiątkowa na cześć Wojciecha Korfantego (1873-1930), znanego przywódcy powstań śląskich, Rudyszwałt (Rudolswald 1305), Rudziczka (Ruderi villa 1300), Rychnów (Rychnow 1273, Reichen 1405), Szywałd (in Schonwalde 1305, Szywałd 1845), gw. Szywołt - dziś Świercze.

Dokumenty średniowieczne do XVI w. odnotowują z terenu obecnej Opolszczyzny 97 nazw niemieckich. Najwięcej w powiatach: nyskim - 35, grodkowskim - 17, brzeskim - 16, prudnickim - 12, a w pozostałych od pięciu do jednej nazwy.

Komisja Ustalania Nazw Miejscowości zmieniała nazwy niemieckie według własnych kryteriów regulaminowych. Te stare nazwy pierwotnie niemieckie od dawna miały swoje spolszczone formy, gdyż leżały na obszarach zasiedlonych przez ludność rodzimą. Komisja te nazwy przywróciła, z wyjątkiem Korfantowa i Świercza, które są ustaleniami Komisji.

Spolonizowane nazwy niemieckie można podzielić na trzy grupy:

1) adaptowane na wzór polski, brzmieniowo nawiązujące do nazw niemieckich (polonizacja fonetyczna), np. Bierzów - Bärzdorf, Buszyce - Buchitz, Czachów Tschacht, Oła - Neu Ohlen, Gierszowice - Giersdorf, Hajduki Nyskie - Heyda, Hanuszów - Hannsdorf, Różyna - Rosenthal, Rzymiany - Reimen, Wilamowa - Alt Wilmsdorf;

2) tłumaczenia nazw niemieckich (kalki), np. Bukowie - Buchwald, Biskupów Bischofswalde, Kwiatków - Blumenthal, Łąka - Wiesau, Nowy Dwór - Neuhof, Lipki - Linden, Lisie Kąty - Fuchswinkel, Zielęcice - Grüningen, Janów - Johansdorf;

3) całkowicie niepowiązane z nazwami niemieckimi, np. Borek - Marienhof, Borównia - Waldkretscham, Bożejów - Emilienhütte, Charbielin - Ludwigsdorf, Chorzelin - Klausenberg, Daniszów - Sandhäuser, Poręby - Sorge.

W wyniku drugiej kolonizacji niemieckiej, tzw. fryderycjańskiej, za czasów Fryderyka II zakładano w różnym czasie wiele wsi niemieckich z niemieckimi nazwami. Były one lokowane w pobliżu mocnego osadnictwa polskiego ${ }^{30}$. Na całym Śląsku założono wówczas ponad 200 takich osad, a na Śląsku Opolskim 19. Kolonie fryderycjańskie były pod silnym wpływem lokalnego systemu nazewniczego. Po 1945 r. Komisja Ustalania Nazw Miejscowości ochrzciła jedynie 44 osady, przy czym te nowe nazwy wyparły wcześniej istniejące formy lokalne, np. Budenbruk - Buddenbrock - dziś 
Brodnia, Grec - Friedrichsgrätz - dziś Grodziec, Grewnot - Gräfenort - dziś Gratowice, Dancyn - Tauentzin - dziś Okoły, Pulów - Paulshof - dziś Paszów, Helwałd Hellewald - dziś Pogorzałka, Kastel - Karlsthal - dziś Godzików, Syseród - Süssenrode - dziś Młodnik.

Inne nazwy gwarowe Komisja przyjęła jako własne chrzty, niekiedy z pewnymi modyfikacjami, np. Petersgrätz, gw. Petergrec - dziś Piotrówka, Rothaus, gw. Rotuz dziś Osiny, Münchhausen, gw. Mnichus - dziś Mnichus, Rennersdorf, gw. Kolonia Renerowska - dziś Renerówka.

Do omówienia pozostały jeszcze nowe nazwy niemieckie, które nigdy nie miały swoich odpowiedników polskich. Przemianowano je dopiero po 1945 r. Na Opolszczyźnie poświadczonych jest 190 tego typu nazw. Na ich powstaniu zaważyły różne czynniki, takie jak wczesna germanizacja ludności w powiatach: brzeskim, głubczyckim, grodkowskim, namysłowskim, niemodlińskim, nyskim, prudnickim, gdzie nowe osady mogły mieć tylko nazwy niemieckie. Natomiast w innych warunkach rozwijało się osadnictwo niemieckie w trójkącie Opole-Kluczbork-Olesno, gdzie w zwartej masie utrzymywała się ludność polska, a koloniści i ich osady się polonizowały. Często tworzyły się dublety nazewnicze z równoległą nazwą niemiecką i polską, np. Neuhof - Nowy Dwór, Leopoldsdorf - Leopoldowiec. Zwiększenie liczby nowych nazw niemieckich następowało wraz z rozwojem przemysłu i majątków obszarniczych na terenach rolniczych, które na ogół otrzymywały nazwy niemieckie. Podobnie jak poprzednie, nazwy niemieckie, które nie miały odpowiedników polskich, były polszczone według przyjętych zasad regulaminowych. Z dużą dozą ostrożności stosowano tłumaczenia tych nazw. Następowało to wówczas, gdy dopuszczano możliwość, że nazwa niemiecka jest kalką wcześniejszej nazwy polskiej, np. Brzózki - Birkenfeld.

W wielu wypadkach Komisja przyjmowała za podstawę swoich chrztów nazwy przejściowe (n. prz.) (przedkomisyjne) z niewielkimi modyfikacjami, np. Amandów od n. prz. Amantów (Amandshof), Kamienisko od n. prz. Kamienna Góra (Steinberg), Nowy Dwór Prudnicki (Neuhof) od n. prz. Nowy Dwór.

Nazwy niemieckie z członem słowiańskim były polonizowane w całości, np. Piastenthal - Piastowice, Bolkenthal - Bolkowice.

Bardzo wiele nazw niemieckich otrzymywało formy luźno skojarzone, np. Katharinenhof - Uciechów, Heinrichsfelde - Jachów, Sandvorwerk - Dzierzhin, Christianshof - Dzików.

Rzadko nadawano nazwy dźwiękowo ze sobą powiązane, np. Krotfeld - Krotoszyn, Julienthal - Ulianówka. W ograniczonym zakresie posługiwano się zbliżonymi kalkami, np. Dachsberg - Jaźwinka, Waldau - Lesie, Neumühle - Nowy Młyn.

Na Opolszczyźnie notujemy łącznie 313 nazw pierwotnie niemieckich.

Zmiany nazewnicze po $1945 \mathrm{r}$. nie objęły polonizacji chrztów z okresu nazistowskiego, o których Komisja była dobrze poinformowana. Pisze o tym przewodniczący Komisji Stanisław Srokowski. Natomiast zostały one uwzględnione w artykułach hasłowych w pracy Stanisława Rosponda, bez żadnego komentarza we wstępie. Wiadomo, że są to nazwy sztuczne, opracowane na zamówienie polityczne, zmierzające do nadania jak najbardziej niemieckiej szaty nazewniczej niemieckiemu 
Wschodowi. Obecnie są one uwzględniane we wszystkich wykazach naukowych i urzędowych Śląska z rokiem nadania, np. Krężel - Krensel, Pappelhof 1931. Ustawa o mniejszościach narodowych z dnia 6 stycznia 2005 r. (Dz.Urz. nr 17, poz. 141) zabrania ich używania na urzędowych tablicach.

\section{Uwagi o nazwach przejściowych}

Jak już wzmiankowano uprzednio, zanim powołano Komisję Ustalania Nazw Miejscowości nadawaniem polskich nazw zajęły się trzy piony: administracja, zarząd poczt i regionalne zarządy kolei. Nazwy nadawała swoim wsiom i miasteczkom także ludność napływowa, np. dzisiejsza nazwa Pokrzywna (Wildegrund) miała aż cztery nazwy: Dzików, Zwierzyniec, Wilczy Dół, a w środowisku turystycznym Śląski Ojców. Te tymczasowe nazwy umownie przyjęto nazywać terminem „nazwy przejściowe” lub „przedkomisyjne” ${ }^{31}$. Wykaz nazw przejściowych Opolszczyzny został opracowany przez Monikę Choroś i Łucję Jarczak ${ }^{32}$. Z zebranego materiału wynika, że 592 miejscowości miały nazwy „tymczasowe”. Część tych nazw Komisja zatwierdziła, sporo przetrwało w potocznym użyciu do dzisiaj, a część po 1989 r. na wniosek mieszkańców stała się nazwami urzędowymi. Oto przykładowe nazwy przejściowe, które nie zostały przyjęte przez Komisję: Bierzów - Bärzdorf - Beredowice $^{33}$, Książkowice - Buchengrund - Czapice, Obórki - Schönfeld - Krzywizny, Strzelniki - Jäderndorf - Karniów, Zawodno - Liehten - Świetlno. Zatwierdzono natomiast nieco poprawione już nazwy, m.in.: Bierawa - Birawa - Birawa, Rybin Riebig - Rybno, Zielony Dąb - Grüneiche - Zielone Dęby, Ogonów - Ogen - Ogony, Lwowiany - Schlegenberg - Osada Lwowska.

Z całej grupy nazw przejściowych Opolszczyzny Komisja nie zaakceptowała 151. Najwięcej nazw „odrzuconych” odnotowano w powiatach: opolskim, strzeleckim, niemodlińskim i prudnickim, a więc tam, gdzie dominowała ludność rodzima.

Porównując nazwy przejściowe z ostatecznymi ustaleniami Komisji, można uznać, że niektóre z nich pod względem językowym były poprawne i nie powinny być odrzucone, np. Słoneczna Góra - Sonnenberg - dziś Krasna Góra, Julianka - Julienthal - dziś Ulianówka, Konradów - Konradsdorf, dziś Konradowa, Ługniany Lugnian - dziś Łubniany.

\section{Zmiany nazewnicze po $1989 \mathrm{r}$.}

Wydawało się, że po tej wielkiej „rewolucji nazewniczej” w latach 1945-1950 nastąpiła stabilizacja polskiego nazewnictwa, a Komisja Ustalania Nazw Miejscowości nie będzie miała ambitniejszych planów. Stało się jednak inaczej. Komisja postanowiła zebrać i opublikować wszystkie nazwy geograficzne kraju i wydać je powiatami w formie niewielkich zeszytów. Prac tych nie doprowadzono jednak do końca,

31 B. Siciński, Pierwsze powojenne polskie nazwy miejscowe na Dolnym Ślasku, „Śląsk Labirynt Krajoznawczy", t. 3 (1991), s. 145.

M. Choroś, Ł. Jarczak, Wykaz przejściowych nazw... 
pominięto cały Śląsk. W tej sytuacji Stanisław Rospond, wieloletni członek Komisji, zorganizował zespół młodej kadry językoznawców na Uniwersytecie Wrocławskim, który prowadził eksploracje terenowe, zapisując wszystkie nazwy używane w danej miejscowości, posiłkowali się oni wiedzą miejscowej ludności. Materiały te wprawdzie nie zostały opublikowane $\mathrm{w}$ formie zeszytów, jak nazwy z regionów centralnych, to jednak ocalały i zastosowano je w opracowanym Słowniku etymologicznym nazw geograficznych Ślaska.

Ludność Śląska broniła się przed przyjęciem nazw ustalonych przez Komisję. Uważała je za narzucane i nie tylko nie chciała wprowadzać ich w życie, ale wręcz protestowała. Mieszkańcy wsi i miast traktowali nazwy jako swoją własność, którą mogą zmieniać, jak im się podoba. O trudnościach we wprowadzaniu nazw w praktyce informowało m.in. Ministerstwo Ziem Odzyskanych w Okólniku nr 25 z 1 lipca 1947 r.:

[...] Równocześnie jeszcze raz stwierdzam, że wprowadzenie w życie ogłoszonych w „Monitorze" nazw urzędowych postępuje bardzo powoli, szczególnie na Śląsku. Używane są nadal nazwy niewłaściwe, stanowiące najczęściej nieudane tylko przeróbki nazw niemieckich. Dzieje się to tylko wskutek pewnych oporów ze strony miejscowej ludności, ale przede wszystkim dzięki niedbałemu ustosunkowaniu się do tego zagadnienia, a nawet niekiedy samowoli lokalnych czynników urzędowych, które używają nazw niezgodnych z brzmieniem głoszonym w „Monitorze Polskim” ${ }^{34}$.

Przez wiele lat mieszkańcy wsi walczyli o prawo współdecydowania o nazwach swoich miejscowości. Dopiero jednak po 1980 r. Komisja mogła przyjąć kilka ważnych ustaleń metodologicznych, m.in. wypracowano projekt, że nie można dokonywać żadnych zmian nazw bez zgody mieszkańców danej miejscowości. Wnioski mogą składać organy władzy samorządowej po uzyskaniu aprobaty większości mieszkańców, potwierdzonej głosowaniami, i po dołączeniu do wniosku protokołu z posiedzenia rady sołeckiej czy gminnej wraz z listą obecności. Wniosek musi być uzasadniony merytorycznie i uzyskać zgodę gminy, a także wojewody. Tryb składania wniosków, a także proces dokonywania zmian nazwy szczegółowo został usankcjonowany ustawą z 29 sierpnia 2003 r. o urzędowych nazwach miejscowych i obiektach fizjograficznych ${ }^{35}$.

Bardzo ważną i zarazem najbardziej interesującą częścią prac Komisji Ustalania Nazw Miejscowości po 1989 r. było rozpatrywanie napływających wniosków o zmianę nazw przez mieszkańców różnych regionów Polski. Nazwy swoich wsi zmieniają także mieszkańcy Śląska, lecz niewiele wniosków wpływa ze Śląska Opolskiego. Jest bowiem kilka przyczyn, które okazują się ważne dla lokalnych społeczności.

34 Cyt. za: M. Choroś, Ł. Jarczak, Przejściowe nazwy miejscowe na Ślasku w latach 1945-1948 (na przykładzie Opolszczyzny), [w:] Najnowsze przemiany nazewnicze, red. E. Jakus-Borkowa, K. Nowik, Warszawa 1998 , s. 168 
Z wnioskami o zmianę nazw bardzo często występują lokalne władze administracyjne (gmina, województwo), kierując się potrzebami porządku administracyjnego. Szybkie zmiany zachodzące w Polsce w ostatnich latach powodują, że wiele starych nazw zanika, gdyż likwidowane są obiekty lub zmienia się ich status; części wsi stają się przysiółkami, np. Łęg, część wsi Tanina stała się w 2008 r. przysiółkiem wsi Tanina. W tej grupie mieszczą się też chrzty nieużywane przez mieszkańców, np. Mnichów - dziś Mnichus.

Charakterystyczne dla Opolszczyzny są petycje o zmiany nazw z postaci literackiej na formy gwarowe, np. Grabczak - Grabczok, Kolankowice - Kolonkowice, Marcinek - Morcinek, Trawniki - Trowniki.

Nadsyłane ze Śląska wnioski o zmianę nazw miejscowości mają jeszcze inne uzasadnienia. Część z nich dotyczy samej formy językowej i poprawności gramatycznej, szyku członów, np. Nowy Bieruń na Bieruń Nowy czy motywacji prestiżowych, gdy nazwa jest w ich odczuciu ośmieszająca, np. Rusków (Rauske) - dziś Raskie, forma oparta na substytucji niemieckiej Rauske. Dla ludności kresowej w powiecie brzeskim nazwa Rusków kojarzyła się z przezwiskiem Rusek „Rosjanin”.

\section{Podsumowanie}

Niniejszy artykuł stanowi pierwszą próbę omówienia historii zmian nazw miejscowości na Śląsku Opolskim po 1945 r. aż do dzisiaj, dokonywanych przez państwowy organ, jakim była i jest Komisja Ustalania Nazw Miejscowości i Obiektów Fizjograficznych. Tuż po wojnie aktywnie w procesie tych przemianowań uczestniczył Instytut Śląski w Katowicach jako współtwórca Komitetu Nazw Geograficznych przy PAU, przy którym utworzono Komisję Śląską.

Oceniając z perspektywy lat pracę Komisji Ustalania Nazw Miejscowości i Obiektów Fizjograficznych (nazwa została zmieniona w 1948 r.), należy uznać, że jej wyniki są zadowalające, a nawet imponujące, mimo pewnych potknięć i braków. Ze strony uczonych był to akt dobrej woli i poświęcenia, gdyż prace członków Komisji nie były honorowane. Pokrywano jedynie koszty przejazdów i noclegi, prace kancelaryjne, głównie maszynistek, korektorek itp.

Przeprowadzenie tego pilnego zadania - uporządkowania nazewnictwa - wymagało rozległej wiedzy językoznawczej, znajomości bazy źródłowej i geografii. Bezcenną pomocą w pracach Komisji były mapy sztabowe. Lwią część prac przygotowywały Komisje Regionalne pracujące ciągle i we współpracy z rozbudowanymi już w tym kierunku pracowniami naukowymi w Instytucie Śląskim w Katowicach, w Instytucie Bałtyckim i Instytucie Zachodnim.

Schemat organizacyjny akcji przywracania nazw polskich na tzw. Ziemiach Odzyskanych był następujący:

- prace przygotowawcze i uchwały Komisji Regionalnych;

- uchwały Komisji Głównej,

- zatwierdzenie przez Ministra Administracji Publicznej i Ziem Odzyskanych,

- ogłoszenie w „Monitorze Polskim”.

Na podkreślenie zasługuje tempo wykonywania pracy, co zaskoczyło stronę niemiecką, która zwróciła się do Międzynarodowej Unii Pocztowej z postulatem, żeby 
w korespondencji międzynarodowej dalej obowiązywały na „Ziemiach Odzyskanych" dotychczasowe nazwy niemieckie, ponieważ polskich nazw było brak i świat o nich nic nie wie ${ }^{36}$. Rząd polski miał już ponad 23 tys. nazw oficjalnych i odpowiedział, że nie ma żadnego problemu międzynarodowego.

Wiele nazw powstałych po 1945 r. na całych "Ziemiach Odzyskanych" to tzw. chrzty, nazwy nieautentyczne, często błędne. Z punktu widzenia językowego należy je traktować inaczej aniżeli nazwy z centralnej Polski. Powstały one w wyniku historycznych przemian politycznych i nie wolno ich zmieniać bez porozumienia z mieszkańcami i oczywiście z organem państwowym, tj. Komisją Ustalania Nazw Miejscowości i Obiektów Fizjograficznych ${ }^{37}$.

Nazwy geograficzne stanowią cenne dziedzictwo kulturowe ludzkości i dlatego wymagają ochrony prawnej. Każda nazwa jest dobrem ogólnoludzkim, istotnym zabytkiem kultury narodowej. Nazwy mówią wiele o przeszłości, są świadkami życia poprzednich pokoleń, uformowane zostały przez wielowiekową tradycję. Dlatego poprawność i stabilność nazw ma wielkie znaczenie dla życia społecznego i administracyjnego ${ }^{38}$.

37 Autorka artykułu była członkiem Komisji w latach 1997-2005.

38 S. Sochacka, Pragmatyczna działalność urzedowych organów nazewniczych w Polsce w okresie powojennym, [w:] Polityka państw narodowych wobec języka na Górnym Ślq̨sku w XIX i XX wieku, red. M. Lis, Ł. Jarczak, L. Drożdż, Opole 2013, s. 33-45. 


\section{Bibliografia}

Borek H., Kolonizacja fryderycjańska na Górnym Ślqsku w odbiciu nazewnictwa miejscowego, „Studia Śląskie", t. XLVII (1989), s. 21-51

Borek H., Opolszczyzna w świetle nazw miejscowych, Opole 1972

Choroś M., Jarczak Ł., Przejściowe nazwy miejscowe na Śląsku w latach 1945-1948 (na przykładzie Opolszczyzny), [w:] Najnowsze przemiany nazewnicze, red. E. Jakus-Borkowa, K. Nowik, Warszawa 1998

Choroś M., Jarczak Ł., Wykaz przejściowych nazw miejscowych na Opolszczyźnie w latach 1945-1948, „Onomastica", t. XLIII (1998), s. 53-80

Choroś M., Jarczak Ł., Sochacka S., Słownik nazw miejscowych Ślqska polsko-niemiecki i niemiecko-polski, Opole 2015

Damroth K., Die älteren Ortsnamen Schlesiens, ihre Entstehung und Bedeutung, mit einem Anhang über die schlesisch-polnischen Personennamen, Beuthen 1896

Iwicki W., Ocena reslawizacji nazw miejscowych w byłym powiecie słupskim przez KUNM, „Zeszyty Naukowe Wydziału Humanistycznego. Filologia Polska. Prace Językoznawcze", nr 11 (1985)

Knie J.G., Alphabetisch - statistisch - topographisches Übersicht der Dörfer, Flecken, Städte und anderen Orte der Königlichen Preusischen Provinz Schlesiens, Breslau 1845.

Nazwa dokumentem przeszłości regionu. Tom poświęcony Wielkiemu Profesorowi Stanisławowi Rospondowi, red. J. Nowosielska-Sobel, G. Strauchold, W. Kucharski, Wrocław 2010

Nitsch K., Nazwy miejscowe w odzyskanej Polsce Zachodniej, „Język Polski”, t. XXV (1945), nr 2, s. 33-41

Olszewicz B., O naprawę nazewnictwa geograficznego Ziem Odzyskanych, Gdańsk-Bydgoszcz-Toruń 1946

Rospond S., Słownik etymologiczny nazw geograficznych Śląska, t. 1: A-B, Warszawa-Wrocław 1970

Rospond S., Słownik nazw geograficznych Polski Zachodniej i Północnej według uchwał Komisji Ustalania Nazw Miejscowych pod przewodnictwem S. Srokowskiego, cz. 1: Polsko-niemiecka, cz. 2: Niemiecko-polska, Wrocław 1951

Rudnicki M., Pierwszy zjazd językoznawców polskich w Szczecinie, „Polska Zachodnia”, nr 8 (1945)

Rymar E., Ocena ustalania nazw miejscowych na obszarze dawnej Nowej Marchii przez Komisję Ustalania Nazw Miejscowych w latach 1946-1949, „Onomastica”, t. XXX (1986), s. 51-68

Rymut K., Działalność Komisji Ustalania Nazw Miejscowości i Obiektów Fizjograficznych w latach 1978-2003, „Onomastica”, t. XLVIII (2003), s. 315-328

Rymut K., Działalność powojennej Komisji Ustalania Nazw Miejscowości z perspektywy kilkudziesięciu lat, „Zeszyty Naukowe Wydziału Humanistycznego Uniwersytetu Gdańskiego. Filologia Polska. Prace Językoznawcze", nr 10 (1984), s. 87-91

Rzetelska-Feleszko E., Zagadnienia poprawności dzisiejszych nazw geograficznych na Pomorzu Zachodnim, [w:] Język i jego odmiany w aspekcie porównawczym, „Prace Slawistyczne”, nr 53 (1986), s. 149-161

Schlesisches Ortschaftsverzeichnis, Tl. 1: Alphabetisches Verzeichnis sämtlicher Städte, Flecken, Dörfer und sonstiger Ortschaft - und Wohnplätze Gesamtschlesiens mit Ausnahme der ehemals polnischen Gebiete. Auf Grund amtliecher Unterlagen, und bearb. 13. Aufl., Breslau 1941

Schummel J.G., Schummels Reise durch Schlesien in Julius und August, 1791, Breslau 1792

Siciński B., Pierwsze powojenne polskie nazwy miejscowe na Dolnym Ślq̨sku, [w:] Ślq̨ski Labirynt Krajoznawczy na Dolnym Ślqsku, Wrocław 1991

Skorowidz gmin Ślq̨ska Dolnego i Opolskiego z niemieckimi i polskimi nazwami miejscowości według stanu z dnia 1 stycznia 1941 r., Katowice 1945 
Słownik etymologiczny nazw geograficznych Śląska, t. 2: C-E, t. 3: F-G, red. S. Rospond, H. Borek, Warszawa-Wrocław 1985-1986

Słownik etymologiczny nazw geograficznych Ślqsska, t. 4: H-Ki, red. H. Borek, Warszawa-Wrocław 1988 Słownik etymologiczny nazw geograficznych Ślqska, t. 5: Kl-Kos, t. 6: Kos-Lig, t. 7: Lig-Miez, t. 8: MięNiż, t. 9: Noc-Path, t. 10: Pato-Poz, t. 11: Poż-Roz, t. 12: Roż-Sów, t. 13: Spad-Szyw, t. 14: Ściana-Wet, t. 15: Wem-Wrzes, t. 16: Wrzesień-Żyznów, t. 17: Suplement A-Ż, red. S. Sochacka, Opole 1991-2016

Sochacka S., Pragmatyczna działalność urzędowych organów nazewniczych $w$ okresie powojennym, [w:] Polityka państw narodowych wobec języka na Górnym Ślq̨sku w XIX i XX wieku, red. M. Lis, Ł. Jarczak, L. Drożdż, Opole 2013, s. 33-45

Sochacka S., Problematyka Ślq̨ska w działalności Komisji Ustalania Nazw Miejscowości i Obiektów Fizjograficznych (ze szczególnym uwzględnieniem lat 1989-2009), „Studia Śląskie”, t. LXIX (2009), s. $195-215$

Srokowski S., Akcja przywracania polskich nazw na Ziemiach Odzyskanych, „Przegląd Geograficzny”, t. XXII (1950), s. 305-309

Stojanowska T., Kazimierz Nitsch a Ślq̨sk. Zwiq̨zki naukowe i kontakty osobiste, Opole 1970

Taszycki W., W obronie ślqskich nazw miejscowych, „Zaranie Śląskie”, t. XVII (1946), s. 52-55

Urbańczyk S., Poczq̨tki działalności Głównej Komisji Ustalania Nazw Miejscowości na Ślqsku i Ziemi Lubuskiej, [w:] Gwary i nazewnictwo na Ziemiach Zachodnich i Północnych, red. E. Homa, Zielona Góra 1998

Urbańczyk S., Porządkowanie nazw miejscowych, „Przegląd Zachodni”, nr 2 (1947), s. 836-841

Wagińska-Marzec M., Jak zmieniano nazwy miejscowości na Warmii i Mazurach po 1945 r., [w:] Wspólne dziedzictwo? Ze studiów nad stosunkiem do spuścizny kulturowej na Ziemiach Zachodnich i Północnych, red. Z. Mazur, Poznań 2000, s. 59-107

Wagińska-Marzec M., Ustalanie nazw miejscowości na Ziemiach Zachodnich i Północnych, [w:] Wokół niemieckiego dziedzictwa kulturowego na Ziemiach Zachodnich i Pótnocnych, red. Z. Mazur, Poznań 1997, s. 369-416 


\section{Zmiany nazw miejscowych na Ślqsku Opolskim po 1945 r.}

Streszczenie: Po zakończeniu wojny na Ziemiach Zachodnich i Północnych brakowało wielu uregulowań dotyczących szczególnie ważnych przejawów życia, m.in. nazewnictwa, wymagającego całościowego ujednolicenia. Przemianować należało nazwy: miast, wsi, osad, przysiółków, gór, jezior i rzek, które funkcjonowały pod urzędowymi nazwami niemieckimi. W artykule został przedstawiony i oceniony proces ustalania nazw miejscowych na Śląsku Opolskim po 1945 r. Praca składa się z kilku części i omawia m.in. następujące zagadnienia: genezę i historię Komisji Ustalania Nazw Miejscowości, powołaną w styczniu 1946 r. przez Ministerstwo Administracji Publicznej; udział Instytutu Śląskiego w Katowicach w pracach Komisji, który odgrywał kluczową rolę w repolonizacji nazewnictwa śląskiego, ponieważ Śląsk dysponował bogatym zasobem dokumentów historycznych; repolonizację nazw miejscowych Śląska Opolskiego, polegającą na rekonstrukcji dawnych nazw polskich opartych na zapisach historycznych; polonizację nazw miejscowych, które przed 1945 r. miały od początku nazwy niemieckie; nazwy przejściowe (przedkomisyjne) nadawane spontaniczne przez ludność miejscową i napływową; zmiany nazewnicze po 1989 r. dokonywane na życzenie mieszkańców wsi. W tym celu Komisja Ustalania Nazw Miejscowości przyjęła projekt ustawy w sprawie trybu składania wniosków przez organy samorządowe.

\section{Changes of place names in Opolian Silesia after 1945}

Abstract: After the end of the war in the Western and Northern Territories there was a lack of many rules relating to individual important expressions of life, among others naming conventions, demanding total harmonisation. There was a need to rename towns, villages, settlements, farms, mountains, lakes and rivers which all functioned under offical German names. The article presents and evaluates the process of determining place names in Opolian Silesia after 1945. The study is divided into several parts and discusses, among others, the following issues: the origin and history of the Commission for Determining Place Names, convened in January 1946 by the Ministry of Public Administration; the contribution to the work of the Commission of the Silesian Institute in Katowice, which played a key role in the Repolonisation of Silesian nomenclature, as Silesia had at its disposal a rich archive of historical documents; the Repolonisation of place names in Opolian Silesia rooted in the reconstruction of former Polish names based on historical records; the Polonisation of the names of places which before 1945 had from their beginnings had German names; temporary names (pre-commission stage) given spontaneously by local and migrant people; changes in naming after 1989 effected at the behest of rural residents. To this end, the Commission for Determining Place Names adopted a policy to govern the process of submitting requests through local authorities.

Słowa kluczowe: onomastyka, toponimy, zmiany nazw na Śląsku Opolskim, germanizacja nazewnictwa, geografia

Key words: onomastics, toponymy, name changes in Opolian Silesia, Germanisation of nomenclature, geography 